\title{
Historical account of monitoring the North Anatolian Fault at the Ismetpasa segment and the latest findings
}

\author{
C. Mekik, H. Kutoğlu \& K. S. Gormus \\ Department of Geomatics Engineering, Bulent Ecevit University, Turkey
}

\begin{abstract}
North Anatolian Fault (NAF) is the largest and longest earthquake producing fault of Turkey which extends from its Iranian border in the east to Marmara Sea in the west with a length of $1200 \mathrm{~km}$. It separates the Eurasian Plate and the Anatolian Plate and has similar features to the San Andreas Fault in California in USA in that both faults have a right-lateral strike slip faulting mechanism, similar lengths and linearity as far as their poles of rotation are concerned. NAF is considered to be one of the longest and most active fault systems in the world, and thus has been the stage of 11 major earthquakes $\left(M_{w}>6.7\right)$ since 1939 . Two of these major earthquakes occurred in the Ismetpasa segment of the fault, located $350 \mathrm{~km}$ east of Istanbul at the intersection of Karabuk and Cankiri provinces in north-central Anatolia, the Asia Minor, and 100km north of Ankara, the capital of Turkey. The Ismetpasa segment of NAF stands out with its aseismic fault slip feature, also referred to as creeping, as the rare occurrence in the world. The Ismetpasa first drew attention by a gradually enlarging crack on the wall of State Highway Maintenance Station built in 1957 and its aseismic slip movement that caused an offset in the wall was first reported in 1969 by Ambraseys. Since then, many researchers have investigated the creep by conducting various measurement methods from conventional surveying techniques to modern techniques such as GPS, LIDAR, InSAR. This paper documents the studies carried on NAF at Ismetpasa segment in a chronological perspective, and also gives the latest findings obtained by different research groups in the last decade.

Keywords: North Anatolian Fault, Ismetpasa segment, fault creep, geodetic measurements.
\end{abstract}




\section{Introduction}

The North Anatolian Fault (NAF has a length of approximately $1200 \mathrm{~km}$ and is one of the most earthquake producing faults in the world and [1]. It has been known to be a natural research laboratory for studying the kinematic and dynamics of plate interactions [2] due to the various tectonic process involved such as diverse phases of continental collision (Zagros/Caucasus/Black Sea), subduction of ocean floor and related ack arc spreading (Cyprus/Hellenic /Calabrian arcs, Aegean and Tyrrhenian Seas), continental expansion (western Turkey/ Marmara Sea/Gulf of Corinth), continental escape (Anatolia), major continental strike slip faults (North and East Anatolian and Dead Sea faults) and a variety of minor movements mostly resulting from African-Arabian-Eurasion plate interactions [3]. NAF constitutes a border between Eurasian and Anatolian plates with a westward movement with Anatolian Block mainly because of the collision of the Arabian and African plates against the Eurosian, Anatolian and Black Sea plates [4-7]. NAF was formed by progressive strain localization in a generally westerly widening right-lateral keirogen in northern Turkey mostly along an interface juxtaposing subduction-accretion material to its south and older and stiffer continental basements to its North [6] (Fig 1).

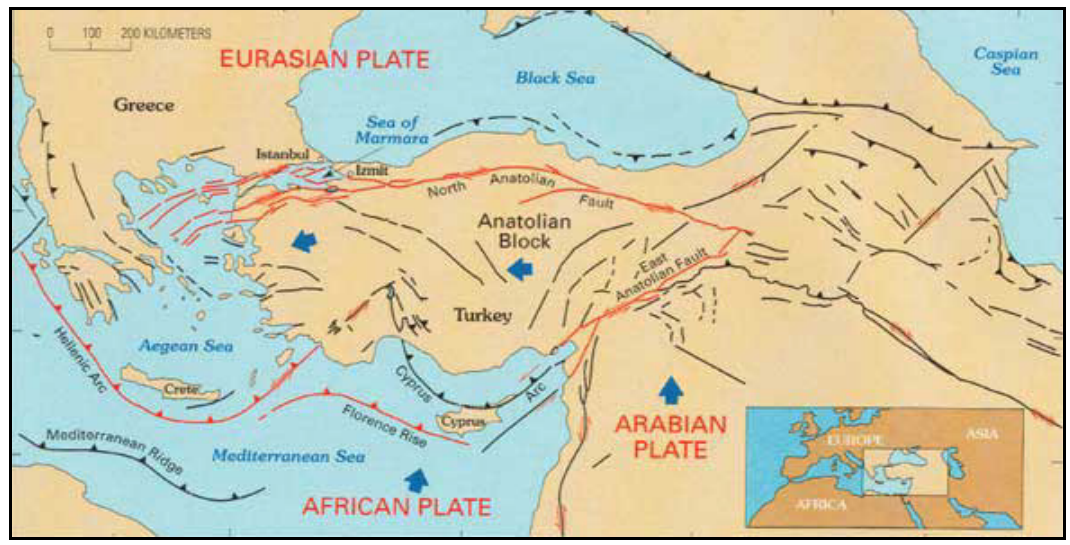

Figure 1: $\quad$ North Anatolian Fault in Anatolian Block and surrounding tectonic plates (courtesy of Comet+ [8]).

NAF is also identified with its dextral strike-slip fault mechanism with a shape of broad arc which produces remarkable seismic activity. It extends from its Iranian border in the east to the north of Aegean in the west, and consists of a few shorter sub-parallel fault strands exhibiting an anastomosing pattern along much of its length. NAF attains a triple junction and joins with the sinistral East Anatolian Fault at Karliova from which continues toward south east [9]. This part of the world has been the focus of many geologic, geophysical and geodetic researches [10-13]. 
The history of the NAF is full of devastating earthquakes killing many thousands of people and causing economic loss. In the last century the NAF has been the stage for 11 devastating major earthquakes measuring around and over 7.0 in magnitudes since the Erzincan earthquake in $1939(\mathrm{Mw}=7.9)$ killing over 32000, namely Niksar-Erbaa in 1942 (Mw=6.9), Tosya-Ladik in 1943 $(\mathrm{Mw}=7.7)$, Bolu-Gerede in $1944(\mathrm{Mw}=7.5)$, Karliova in $1949(\mathrm{M}=7.1)$, Kursunlu in $1951(\mathrm{Mw}=6.9)$, Abant in $1957(\mathrm{Mw}=6.8)$, Varto in $1966(\mathrm{Mw}=6.9)$ killing 2400 and injuring 1500 people, Mudurnu in 1967 (Mw=7.1), Erzincan in 1992 $(\mathrm{Mw}=6.5)$, and the recent major earthquakes in Izmit in 17 August 1999 $(\mathrm{Mw}=7.6)$ killing over 17000 and injuring 44000 people and Duzce on 12 November $1999(\mathrm{Mw}=7.2)$ killing almost 900 people [14].

The NAF is found similar to the San Andreas Fault in California in features that both faults have right-lateral strike slip faulting mechanism, similar lengths and linearity as far as their poles of rotation are concerned [15]. Plate tectonic models analyzing fault systems and earthquake slip vector described in DeMets et al. [16] and Jestin et al. [17] demonstrate that Arabian plate is moving in a NNW direction relative to Eurasia at a rate of $18-25 \mathrm{~mm} / \mathrm{yr}[3,18]$. The most important findings in relation to these earthquakes is that they have a progressive failure systematic migrating westward [15]. In this respect, a next major earthquake is expected on its branches in the Marmara Sea [19].

\section{Ismetpasa segment of North Anatolian fault}

Ismetpasa segment of the North Anatolian Fault stands out with its aseismic fault slip feature, also referred to as fault creep, or just the creep. It is located $350 \mathrm{~km}$ east of Istanbul and $100 \mathrm{~km}$ northwest of Ankara, the capital of Turkey, at the intersection of Karabuk and Cankiri provinces in north-central Anatolia, the Asia Minor. Since the fault creep feature is what makes Ismetpasa segment of the NAF so distinct, it deserves some elucidation.

The main rationale for sturdy and destructive earthquakes is that most of the locked active faults accumulate strain over a long period of time in the so-called seismogenic depth interval and when the strain loaded on the fault becomes unbearable, the sudden release of energy leads to devastating tremors [20]. Findings from many researchers indicate that the upper crust on some segments of world renowned faults is where fault creep can be encountered as are the cases for San Andreas Fault (SAF) [21], the Hayward Fault [22], the Superstition Hills Fault [23] and the North Anatolian Fault (NAF) [24]. Fault creeping is assumed to inhibit the accumulation of potential energy of elastic deformation and increase in stress providing that its rate matches the long-term fault slip rate, thus resulting in no large earthquake [20]. On the other hand, when the rate of fault creep is much lower than the long-term slip rate, it is possible that the fault with creeping motion is inclined to generate moderate to large magnitude earthquakes [20].

Although the occurrence of creep is well documented, the interactions between locked and creeping portions of a fault and the conditions leading to creep, causes and the depth extent of creep on faults are not well understood 
[25]. The factors that can be attributed to play important roles in the creeping processes are the geometry of the fault segment with creeping occurrence, the length of the creeping segment, the degree of coupling on the fault surface and the rheological properties of the lithosphere [26, 27].

Ismetpasa segment of the NAF has not been seismically active for over nine centuries, the last one occurred at a nearby settlement Hamamlı in 1045 AD, as far as official recordings of earthquakes in Turkey are concerned, instead it is found to be creeping along the NAF from the findings that will be historically explained in further sections of this paper. However, two of the largest earthquakes, out of twelve on the NAF, in the last century occurred in the vicinity of Ismetpasa segment, namely Gerede earthquake in $1944(\mathrm{Mw}=7.2)$ in the western tail and Kursunlu earthquake in $1951(\mathrm{Mw}=6.9)$ in the eastern tail of the fault [28]. It is reported that both earthquakes inflicted offsets on the surface in the Ismetpasa segment, especially the Gerede earthquake with a surface rupture of $160 \mathrm{~km}$, creating vertical displacements of $10-40 \mathrm{~cm}$ to the north and south of the main rupture [29]. Although the Kursunlu earthquake did not rupture as much as the Gerede earthquake but still managed to cause a surface rupture 32 $\mathrm{km}$ long with a $60 \mathrm{~cm}$ dextral strike-slip offset and a $30 \mathrm{~cm}$ vertical displacement with a downthrown northern block [30].

The following sections gives detailed account of measurements and analyses conducted on Ismetpasa segment of the NAF. In order for readers to make sound comparisons and arrive at valid conclusions, the historical account of monitoring measurements are investigated in two separate sections, namely conventional and modern monitoring measurements at the Ismetpasa segment.

\section{Conventional monitoring measurements at the Ismetpasa segment}

Ambraseys [31] was the first scientist to observe the fault creep at the Ismetpasa segment when noticed a cracked wall of State Highway Maintenance Station, or the railway station. He immediately measured the width of the crack on the wall with tape meter and obtained $24 \mathrm{~cm}$, which gave a $2 \mathrm{~cm} / \mathrm{yr}$ creeping rate by taking into account of twelve years of time span between the building date (1957) of the wall and measurement date (1969). He stumbled on this discovery when he came to Turkey in 1969 to investigate the ruptures on the NAF since the devastating Erzincan earthquake in 1939. During his visit to the location late spring of 1969, he found that the wall facing east sheared off and displaced in a right-lateral sense by $24 \mathrm{~cm}$, and the longer wall facing south compressed by approximately $5 \mathrm{~cm}$. After carefully examining the fault zone, in line with the crack in the wall, he encountered no apparent offsets a few kilometers on either side of Ismetpasa.

This movement at a railway station initiated the first efforts to determine the crustal movements by geodetic methods in the west section of the NAF. Aytun [32] conducted a conventional geodetic network at Ismetpasa segment from 1957 to 1969 and arrived at a creep rate of $15 \mathrm{~mm} / \mathrm{yr}[32,25]$ and of $11 \mathrm{~mm} / \mathrm{yr}$ from 1969 and 1978 [32, 33]. Ugur [34] established a microgeodetic network for his 
Ph.D. study in 1969, but the displacement he found was within the error budget therefore no significant movement was ascertained with high accuracy and precision.

In 1972, two microgeodetic networks were established one in Ismetpasa and the other in Gerede by the General Command of Mapping. Both triangulation networks were measured in 1972 and 73. The Ismetpasa network was later measured by Eren [35] in 1982 and Deniz et al. [36] in 1992 using horizontal angles and electromagnetically measured distances by Geodesy Working Group in Istanbul Technical University. The first period of this 1972 network in Ismetpasa were conducted using slant distances which then were reduced to Gauss projection plane on which the network adjustment were done. During the adjustment of the network, the points on the Eurasion plate were chosen as reference points. The Doppler observations carried out on the same network were adjusted in the same fashion in 1982 by Eren [35]. As a third period, the terrestrial observations were repeated in 1992 by Deniz et al. [36], only this time without one observation point, namely point 5 , since it had been destroyed during all the years past. The creep slip rates computed by these terrestrial measurements campaigns are listed in Table 1.

Table 1: Summary of the analyses of the Ismetpasa terrestrial network (derived from Deniz et al. [36]).

\begin{tabular}{lccc}
\hline \multicolumn{1}{c}{ Analyses } & $\mathbf{1 9 7 2 - 8 2}$ & $\mathbf{1 9 8 2 - 9 2}$ & $\mathbf{1 9 7 2 - 9 2}$ \\
\hline Deformation vector (mm) & 111.2 & 87.1 & 192.9 \\
Azimuth of def. vec. (gon) & 250.1 & 253.1 & 243.0 \\
Creep rate (mm/yr) & 11.1 & 8.7 & 9.6 \\
\hline
\end{tabular}

As can be clearly seen from Table 1, it is possible to take individual campaigns in their own right and arrive at deductions for the creep rates as $11.1 \pm 3.3 \mathrm{~mm}$ for the $1972-82$ period and $8.7 \pm 3.7 \mathrm{~mm}$ for the $1982-92$ period as opposed to the lump sum of both campaigns and stating one creep rate as $9.6 \pm 3.0 \mathrm{~mm}$, depending on the point of view.

Altay and Sav [37] measured a creep rate of 7.7mm/yr between 1982 and 1990 just using creepmeter readings. Saroglu and Barka [38] made a tape meter measurement on the cracked railway station wall and obtained $40 \mathrm{~cm}$ total creep since the building of the wall in 1957, which gives a slow creeping rate of $11 \mathrm{~mm} / \mathrm{yr}$.

\section{Modern monitoring measurements at Ismetpasa segment}

The first study conducted by Cakir et al. [39] utilized modern instrumental creep monitoring method: Interferometric Synthetic Aperture Radar (InSAR) after the two devastating earthquakes occurred in 1999 three months apart (the Izmit earthquake on $17^{\text {th }}$ August with $\mathrm{Mw}=7.6$ and the Duzce earthquake on $12^{\text {th }}$ November with $\mathrm{Mw}=7.2$ ) along the NAF. This study contained more than seven usable interferograms out of 20 due to temporal decorrelation from SAR images 
between 1992 and 2002 using SRTM 3-arcsecond data for the removal of topographic phase.

A modern technique called Interferometric Synthetic Aperture Radar (InSAR) has been utilized for manmade surface deformations as well as land movements and fault creeping. It has emerged since the turn of the century in collecting data and anomalies in earth surface [40]. The term interferometric is derived from interference which is formed by combination of two waves of light, sound, electromagnetic and etc. origin. InSAR gives way to the production of interferogram which is the outcome image of common pixels in both images and their computed phase differences for the same area. Interferogram is the interference pattern of fringes emerging due to the phase differences of the two images for the same pixels. Each cycle of phase or fringe in an interferogram corresponds a distance alteration on earth equal to a half wavelength [41]. Radar Interferometry technique provides a means to monitor earthquakes, volcanic movements, glacial movements and rebounds, landslides, surface deformations fault slips etc. [42].

The measurements conducted by Cakir et al. [39] indicate that at the western termination of the 1943 earthquake rupture fault creep initiates to the east and continues approximately $70 \mathrm{~km}$ to the west overlapping with the eastern part of the 1944 earthquake fault segment. The InSAR data obtained by the same study produced a creep rate of $8 \pm 3 \mathrm{~mm} / \mathrm{yr}$ around Ismetpasa segment of the NAF.

Kutoglu and Akcin [43] conducted a geodetic observation campaign in 2002 using another modern technique called Global Positioning System (GPS). For their GPS observations they utilized the micro-geodetic network established by the General Command of Mapping and used by both Eren [35] and Deniz et al. [36]. This micro-geodetic network, also called as the Ismetpasa trilateration network, contained three points on the Eurasian plate and three points on the Anatolian block. For the GPS campaign, the observations were done in 1-hour site occupation in static mode of relative positioning, and slope distances between the points were obtained as well as absolute and relative coordinates of the points. The reason for utilizing the distances in this work is that they are independent of datum in three-dimensional space and could therefore be evaluated in any local terrestrial coordinate system. They resorted to using the Helmert (Similarity) transformation to the GPS results after the adjustment in order to eliminate the possible scale difference caused by applying a different surveying method. Accordingly they reached a common solution for the network over a period of the ten years since 1992, and found a fault creep rate of $7.8 \pm 0.5$ $\mathrm{mm} / \mathrm{yr}$ which is consisted with the findings of Cakir et al. [39].

A team of researchers from Bulent Ecevit University (formerly known as Zonguldak Karaelmas University) revisited the micro-geodetic network and conducted a 5-year GPS campaign between 2002 and 2007 [24]. They carried out again $1 \mathrm{~h}$ static GPS observations on the grounds that all the baselines were very short $(>1 \mathrm{~km})$ and one hour site occupation in static mode of relative positioning should suffice to obtain precise positions to monitor the offsets of five years. 
The baselines obtained in this fashion with their precisions ranging from $1.7 \mathrm{~mm}$ to $2.2 \mathrm{~mm}$ exhibited the adequacy and homogeneity for the deformation monitoring purposes. They arrived at a conclusion from this study that the points on the Anatolian block suffered an offset of $12 \pm 0.8 \mathrm{~mm} / \mathrm{yr}$.

The same research team conducted a new GPS campaign for the Ismetpasa segment in the same micro-geodetic network in 2008, but only this time they occupied the sites 8 hours a day over four days [44]. The reason for long occupation times, as they stated, was to establish a global network connection so as to obtain absolute displacements at the network points for future analysis. When they compared the two separate coordinate sets for the object points they obtained the deformation components from $3.4 \mathrm{~mm}$ to $10.5 \mathrm{~mm}$ in the northern direction which translates in a contraction of the network towards the Anatolian block while the eastern component was found to have varied 10.7 to $15.7 \mathrm{~mm}$. They concluded that the surface creep rate of the Ismetpasa segment was computed to be $15.1 \pm 4.1 \mathrm{~mm}$ from the geodetic network based on the average of the total displacement rates between 2007 and 2008.

\section{Latest findings}

Ground-based light detection and ranging (LIDAR), another modern deformation monitoring technique, was used on the two manmade walls at the Ismetpasa segment for the periods of June 2007 and November 2009 by Karabacak et al. [45]. Ground-based LIDAR can be described as an active remote sensing system based on observing the time travelled by a laser beam from the instrument to an object [46]. With millimetre-scale resolution is created a three dimensional point cloud by multiple laser beams in order to obtain virtual-reality models of the surface by turning these clouds into triangulated surfaces [47].

Two walls situated across the 1944 Gerede earthquake rupture were chosen for scanning at $3-\mathrm{mm}$ resolution during six campaigns at Ismetpasa by Karabacak et al. [45] for the ground-based LIDAR campaign,. The results revealed by their surveys indicated a considerable amount of aseismic strain, creeping, along the Ismetpasa segment of the NAF and were given as 8.4 and $9.6 \pm 4 \mathrm{~mm} / \mathrm{yr}$ at the two sites.

Researchers from Bogazici University, Kandilli Observatory and Earthquake Institute, Geodesy Department conducted a 6-year GPS campaign between 2005 and 2011 on the network established by General Command of Mapping in 1972, which was utilized by Eren [35], Deniz et al. [36], Kutoglu and Akcin [43], and Kutoğlu et al. [24]. They carried out $10 \mathrm{~h}$ static GPS observations on 5 points of the network including 18 global IGS reference stations, and found $15.8 \pm 1 \mathrm{~mm} / \mathrm{yr}$ for the average site velocities from six periods of GPS observations with respect to a Eurasia-fixed reference frame [25]. On the other hand, they obtained an average creep rate of $7.6 \pm 1 \mathrm{~mm} / \mathrm{yr}$ for the points south of the fault with respect a reference point north of the fault [25].

Kutoglu et al. [48] revisited the Ismetpasa segment, but this time conducted a GPS campaign as well as Differential InSAR campaigns using two different data, Palsar and Envisat. For GPS observations, they occupied the 6 points of the 
1992 microgeodetic network for three days and $8 \mathrm{~h}$ in the 2008 campaign and $12 \mathrm{~h}$ in the 2010 campaign with $10 \mathrm{~s}$ epochs in both periods. They also included seven International Terrestrial Reference Frame (ITRF) points IGS for datum definition of the geodetic networks. The creep rate was found to be $13 \pm 3.9 \mathrm{~mm} / \mathrm{yr}$ on the basis of 2008 and 2010 GPS observations.

In order to monitor creep motion, they utilized 17 Palsar and 22 Envisat data acquired between 2007 and 2010. The data obtained were processed on the basis of "two-pass method" of Differential InSAR (DInSAR) technique, and also SRTM 90 m digital elevation model data used for eliminating topographic effect in phase interferograms. The deformation interferograms were obtained by applying the weighted power spectrum method for filtering noises [49]. From 17 Palsar images, the surface displacements were positive on the north side of the microgeodetic network, but negative on the southern side with respect to the satellite line of sight based on the fringes in the 33-km-long area, and the creep rate was found to be $13 \pm 2 \mathrm{~mm} / \mathrm{yr}$. The surface displacement obtained from 22 Envisat images were measured $22 \pm 2 \mathrm{~mm}$ eastward for the northern side which is same as the southern part only moving westward, the creep rate was determined to be $12 \pm 1 \mathrm{~mm} / \mathrm{yr}$.

Another work applying InSAR time series analysis for the same region is carried out by Deguchi [50] using Palsar data in order to measure long-term ground deformation from 2007 to 2011 . He concluded that the creep rate along the Ismetpasa segment was $14 \mathrm{~mm} / \mathrm{yr}$ in the line of sight [50].

Kaneko et al. [20] have also reported the high-resolution measurement of interseismic deformation along the Ismetpasa segment of the NAF using InSAR data from the Advanced Land Observing Satellite (ALOS) and Envisat missions along with GPS observations. They integrated InSAR data with GPS observations to correct for long-wavelength errors of InSAR phase data by summing up interferograms to form a stack of line of sight velocity, removing a GPS model from the stack, high-pass filtering the residual stack and restoring the GPS model by adding it back to the filtered residuals [51]. They generated maps of satellite line-of-sight velocity using 5 ascending ALOS tracks and one descending Envisat track covering the Ismetpasa segment completely and beyond, and found a surface creep at a rate of $9 \mathrm{~mm} / \mathrm{yr}$ across the Ismetpasa segment of the NAF for a time period of 4 years between 2007 and 2011.

\section{Conclusions}

NAF has a long history of devastating earthquakes killing many thousands of people and causing economic loss. In the last century NAF has been the stage for 11 devastating major earthquakes measuring around and over 7.0 in magnitudes since the Erzincan earthquake in 1939 ( $\mathrm{Mw}=7.9)$ killing over 32000. The Ismetpasa segment of the NAF sustained two of these major earthquakes occurred in the last century in its vicinity, namely Gerede earthquake in 1944 $(\mathrm{Mw}=7.2)$ in the western tail and Kursunlu earthquake in $1951(\mathrm{Mw}=6.9)$ in the eastern tail of the fault. What makes the Ismetpasa segment of the NAF so 
special is its aseismic fault slip feature, fault creep, as the rare occurrence in the world and being the only one in Turkey.

Ambraseys was the first scientist to discover the creeping feature of the Ismetpasa segment of the NAF. He stumbled on this discovery by noticing a cracked wall at the railway station in Ismetpasa when he came to Turkey in 1969 to investigate the ruptures on the NAF since the devastating Erzincan earthquake in 1939. His discovery initiated the measurement campaigns to take off, as it were, in the region by national and international geologists, geophysicists and geomatics engineers. This study details the historical account of monitoring, measuring, observing campaigns in chorological order. To make it easier for readers to differentiate the results obtained by researchers, the distinction is made to give accounts of conventional and modern monitoring measurements, and the latest findings for the Ismetpasa segment is also included.

\section{References}

[1] Kasapoglu, E.K. and Toksoz, M.N. Tectonic consequences of the collision of the Arabian and Eurasian plates: finite element models. Tectonophysics, 100 pp. 71-95, 1983.

[2] Plag, H-P. Ambrosius, B., Baker, T. F., Gerhard, B., Bianco, G., Blewitt, G., Boucher, C., Davis, J.L., Degnan, J.J., Johansson, J.M., Kahle, H-G., Kumkova, I., Marson, I., Mueller, S., Pavlis, E.C., Pearlman, M.R., Richter, B., Spakman, W., Tatevian, S., Tomasi, P., Wilson, P., Zerbini, S. 1998.

[3] McClusky, S.C., Balassanian, S., Barka, A., Ergintav, S., Georgiev, I., Gurkan, O., Hamburger, M., Hurst, K., Kahle, H., Kastens, K., Kekelidze, G., King R., Kotzev, V., Lenk, O., Mahmoud, S., Mishin, A., Nadaria, M., Ouzounis, A., Paradissis, D., Peter, Y., Prilepin, M., Reilinger, R.E., Sanli, I., Seeger, H., Tealeb, A., Toksoz, N. and Veis, G. Global Positioning System constraints on plate kinematics and dynamics in the eastern Mediterranean and Caucasus. Journal of Geophysical Research, 105(B3), pp. 5695-5719, 2000.

[4] Sengor, A.M.C. The North Anatolian transform fault: its age, offset and tectonic significance. Journal of the Geological Society of London, 136, pp. 269-282, 1979.

[5] Sengor, A.M.C.; Gorur, N. and Saroglu, F. Strike-slip faulting and related basin formation in zones of tectonic escape: Turkey as a case study, The Society of Economic Paleontologists and Mineralogists, Special Publication, 37, pp. 227-264, 1985.

[6] Sengor, A.M.C.; Tuysuz, O., Imren, C., Sakinc, M., Eyidogan, H., Gorur, N., Le Pichon, X. and Rangin, C. The North Anatolian Fault: A New Look. Annual Review of Earth and Planetary Sciences, 33, pp. 37-112, 2005.

[7] Barka, A. and Kadinsky-Cade, K. Strike-slip fault geometry in Turkey and its influence on earthquake activity. Tectonics, 7, pp. 663-684, 1988.

[8] Comet+, http://comet.nerc.ac.uk/for_schools_earthquakes4.html

[9] Bozkurt, E. Neotectonics of Turkey - a Synthesis. Geodinamica Acta, 14, pp. 3-30, 2001. 
[10] Ketin, I. Relations Between General Tectonic Features and the Main Earthquake Regions of Turkey, vol. 71. MTA Publication, pp. 63-67 (in Turkish), 1968.

[11] Canitez, M. The studies about the recent crustal movements and the North Anatolian Fault problem. In: Proceedings, Symposium on the North Anatolian Fault and Earthquake Belt. MTA Publication, pp. 35-58 (in Turkish with English abstract), 1973.

[12] Taymaz, T., Jackson, J.A., McKenzie, D.P. Active tectonics of the north and central Aegean Sea. Geophysical Journal International, 106, pp. 433490, 1991.

[13] Mueller, S., and Kahle, H.-G. Crust-mantle evolution, structure and dynamics of the Mediterranean-Alpine region, in Contributions of Space Geodesy to Geodynamics: Crustal Dynamics, Geodynamics Series, 23, pp. 249-298, 1993.

[14] Bayrak, Y.; Ozturk, S., Koravos, G.C., Leventakis, G.A. and Tsapanos, T.M. Seismicity assessment for the different regions in and around Turkey based on instrumental data: Gumbel first asymptotic distribution and Gutenberg-Richter cumulative frequency law. Natural Hazards and Earth System Sciences, 8, pp. 109-122, 2008.

[15] Stein, R.S., Barka, A., Dieterich, J.H. Progressive failure on the North Anatolian fault since 1939 by earthquake stress triggering. Geophysical Journal International, 128, pp. 594-604. 1997.

[16] DeMets, C., Gordon, R. G., Argus, D.F. and Stein, S. Effects of resent revisions to the geomagnetic reversal time scale on estimates of current plate motions, Geophysical Research Letters, 21, pp. 2191-2194, 1994.

[17] Jestin, F., Huchon, P. and Gaulier, J. M. The Somalia Plate and the East African rift systems: Present-day kinematics, Geophysics Journal International, 116, pp. 637-654, 1994.

[18] Ozener, H., Dogru, A., Unlutepe, A. An approach for rapid assessment of seismic hazard in Turkey by continuous GPS data. Sensors, 9(1), pp. 602615. 2009.

[19] Parsons, T., Toda, S., Stein, R.S., Barka, A., Dieterich, J.H. Heightened odds of large earthquakes near Istanbul: An interaction-based probability calculation. Science, 288, pp. 661-665, 2000.

[20] Kaneko, Y., Fialko, Y., Sandwell D. T., Tong, X. and Furuya, M. Interseismic deformation and creep along the central section of the North Anatolian Fault (Turkey): InSAR observations and implications for rateand-state friction properties, Journal of Geophysics Research Solid Earth, 118, doi:10.1029/2012JB009661, 2013.

[21] Burford, R. O. and Harsh, P. WSlip on the San Andreas fault in central California from alinement array surveys, Bulletin Seismology Society American, 79(4), pp. 1233-1261, 1980.

[22] Titus, S. J., DeMets, C. and Tikoff, B. Thirty-five-year creep rates for the creeping segment of the San Andreas fault and the effects of the 2004 Parkfield earthquake: Constraints from alignment arrays, continuous Global 
Positioning System, and creep meters, Bulletin Seismology Society American, 96, S250-S268, doi:10.1785/0120050811, 2006.

[23] Bilham, R. Surface slip subsequent to the 24 November 1987 Superstition Hills, Bulletin Seismology Society American, 79, pp. 424-450, 1989.

[24] Kutoglu, H. S., Akcin, H., Kemaldere, H. and Gormus, K.S. Triggered creep rate on the Ismetpasa segment of the North Anatolian Fault, Natural Hazards and Earth System Science, 8, pp. 1369-1373, 2008.

[25] Ozener, H., Dogru, A. and Turgut, B. Quantifying aseismic creep on the Ismetpasa segment of the North Anatolian Fault Zone (Turkey) by 6 years of GPS observations, Journal of Geodynamics, doi:10.1016/j.jog. 2012.08.002, 2012.

[26] Malservisi, R. Numerical models of the dynamics of lithospheric deformation at complex plate boundaries. PhD Thesis, Pennsylvania State University, 2002.

[27] Malservisi, R., Gans, C. and Furlong, K.P. Numerical modeling of strikeslip creeping faults and implications for the Hayward fault, California, Tectonophsics, 361, pp. 121-137, 2003.

[28] KOERI, http://www.koeri.boun.edu.tr/sismo/ default.htm

[29] Tasman, C. Gerede-Bolu Earthquake. MTA Publication, Ankara, Turkey, 1/31, pp. 134-139 (in Turkish), 1944.

[30] Ambraseys, N.N., Jackson, J.A. Faulting associated with historical and recent earthquakes in the Eastern Mediterranean region. Geophysical Journal International, 133, pp. 390-406, 1998.

[31] Ambraseys, N. N. Some characteristic features of the Anatolian fault zone, Tectonophysics, 9, pp. 143-165, doi:10.1016/0040-1951(70)90014-4, 1970.

[32] Aytun, A. Creep measurements in the Ismetpasa region of the North Anatolian Fault Zone, in: Multidisciplinary approach to earthquake prediction 2, edited by: Isikara, A. M., Vogel, A., Friedr. Vieweg \& Sohn, Braunschweig, 279-292, 1982.

[33] Kutoglu, H., Akcin, H., Gormus, K.S. and Kemaldere, H. Geodetic works conducted in North Anatolian Fault at Ismetpasa segment, $12^{\text {th }}$ Turkish Scientific and Technical Congress for Surveying, 11-15 May, Ankara (In Turkish), 2009.

[34] Ugur, E. Recent crustal movements in the Gerede-Cerkes region of the North Anatolian Fault zone by geodetic methods, Ph.D. Thesis, Istanbul Technical University. 1974.

[35] Eren, K. Strain analysis along the North Anatolian Fault by using geodetic surveys. Bulletin Geodesique, 58(2), 137-149, 1984.

[36] Deniz, R., Aksoy, A., Yalin, D., Seeger, H., Franke, P., Hirsch, O. and Bautsch, P. Determination of crustal movements in Turkey by terrestrial geodetic methods, Journal of Geodynamics, 18(1-4), pp. 13-22.,1993.

[37] Altay, C. and Sav, H. Continuous creep measurement along the North Anatolian fault zone, (in Turkish) Turk. Jeol. Kurult. Bul. 6, pp.77-84, 1991. 
[38] Saroglu, F. and Barka, A. Implications and importance of continuing postearthquake, long-duration displacement. Geophysics Journal, 9(10), pp. 339-343, 1995.

[39] Cakir, Z., Akoglu, A.M., Belabbes, S., Ergintav, S. and Meghraoui, M. Creeping along the Ismetpasa section of the North Anatolian fault (Western Turkey): Rate and extent from InSAR, Earth Planet Scientific Letters, 238, pp. 225-234, 2005.

[40] Pascazio, V. and Schirinzi, G. Multifrequency InSAR height reconstruction through maximum likelihood estimation of local planes parameters. IEEE Transactions on Image Progressing, 11(12), pp. 1478-1489, 2002.

[41] Cakir, Z., Chabalier, J.B., Armijo, R., Meyer, B., Barka, A. and Peltzer, G. Coseismic and Early Postseismic Slip Associated with the 1999 Izmit earthquake (Turkey), from SAR Interferometry and Tectonic Field observations, Geophysics Journal International, 155, pp. 93-110, 2003.

[42] Delouis, B., Lundgren, P., Salichon, J. and Giardini, D. Joint inversion of InSAR and teleseismic data for the slip history of the 1999 Izmit (Turkey) earthquake, Geophysical Research Letters, 27(20), pp. 3389-3392, 2000.

[43] Kutoglu, H. S. and Akcin, H. Determination of 30-Year Creep on The Ismetpasa Segment of the North Anatolian Fault Using an Old Geodetic Network, Earth Planets Space, 58, pp. 937-942, 2006.

[44] Kutoglu H.S. Datum issue in deformation monitoring using GPS. FIG working week 2010-facing the challenges, Sydney, 11-16 April, 2010.

[45] Karabacak, V., Altunel, E. and Cakir, Z. Monitoring aseismic surface creep along the North Anatolian Fault (Turkey) using ground-based LIDAR, Earth and Planetary Science Letters, 304, pp. 64-70, 2011.

[46] Kemeny, J., Turner, K. Ground-based LIDAR rock slope mapping and assessment. Federal Highway Administration Report, Lakewood, USA, 2008.

[47] POB. Point of Beginning, Laser Scanner Survey, 2008.

[48] Kutoglu, H.S., Gormus, K.S., Deguchi, T., Koksal, E., Kemaldere, H. and Gundogdu, O. Can a creeping segment become a monitor before destructive major earthquakes?, Natural Hazards, 65(3), pp. 2161-2173, 2012.

[49] Goldstein, R.M. and Werner, C.L. Radar interferogram filtering for geophysical applications. Geophysics Research Letters, 25(21), pp. 40354038, 1998.

[50] Deguchi, T. Detection of fault creep around NAF by InSAR time series analysis using PALSAR data. Proc. of SPIE 8179, http://dx.doi.org/10. 1117/12.898478, 81790J, 2011.

[51] Tong, X., Sandwell, D. and Smith-Konter, B. High-resolution interseismic velocity data along the San Andreas fault from GPS and InSAR, Journal of Geophysical Research, doi:10.1029/2012JB009442, 2012. 